\title{
Knowledge, Attitudes and Practice (KAP) Study among Parents about Vaccination in Tertiary Care Hospital of Karachi, Pakistan
}

\author{
Saira Shahnaz ${ }^{1}$, Mudassar Iqbal Arain ${ }^{2}$, Ramesha Anwar ${ }^{3}$, Faiza Khan ${ }^{4}$ \\ 1. Department of Pharmacy Practice, Faculty of Pharmacy, Ziauddin University Karachi, Pakistan. \\ 2. Department of Pharmacy Practice, Faculty of Pharmacy, University of Sindh, Jamshoro, Pakistan. \\ 3. Faculty of Pharmacy, University of Sindh, Jamshoro, Pakistan. \\ 4. MPhil scholar, Department of Pharmaceutics, Faculty of Pharmacy, Ziauddin University Karachi, Pakistan. \\ *Corresponding author's E-mail: msairakhan13022@gmail.com
}

Received: 13-06-2020; Revised: 16-08-2020; Accepted: 22-08-2020.

DOI: $10.47583 /$ ijpsrr.2020.v64i01.005

\section{ABSTRACT}

Administration of vaccine to defend a person's immune system against an infection is called Immunization. It's a prophylactic treatment for many diseases that's the reason the childhood vaccinations have been highlighted. The objective is to assess the knowledge, attitude, and practice (KAP) of parents about vaccination in Zia - Uddin university hospital, Karachi. A cross sectional study was conducted among the parents of young children ( $\leq 5$ years). A tertiary care teaching hospital was selected for collecting the data for the period of 7 months from June 2019 to December 2019 in Karachi. For Collection of data pediatric out patient's department and emergency department of a private hospital of Karachi was targeted. After reviewing the abundant amount of relevant data, a questionnaire was constructed to assess the parental knowledge attitude and perception (KAP) regarding the vaccinations among their child. The results were displayed by frequencies and percentages. A pilot study was conducted among 25 parents to check and optimize clarity of questionnaire. This study showed that total 450 responses were correctly fill the questioner in which (21.3\%) recorded with male gender and remaining were female's preponderance (78.7\%). Most of the parents $(44.7 \%)$ reported were in age group of $30-39$ years. (83.6\%) parents were educated and their source of information was doctors (73.6\%). (6.79\%) of parents marked their children has already suffered from the preventable disease. (85.4\%) of parents have their child vaccination record. $67.9 \%$ of parents remained uncertain had no knowledge regarding the vaccinations. $(27.8 \%)$ of parents stated that a vaccination can produce side effects. Results shows that targeted population have awareness, knowledge and importance of vaccination, and have a positive attitudes and practice pattern regarding vaccination. A satisfying outcomes found in this study. It is observed that most of the participants parents having awareness regarding vaccination and wanted to know about the vaccine benefits.

Keywords: Knowledge, Attitude, Practice, Tertiary care.

\section{INTRODUCTION}

dministration of a vaccine to protect a person's immune system against an infection is called Immunization ${ }^{1}$. It's an important to know that treatment should not only to treat and eradicate the infectious disease but proper prophylaxis against them should also be carried out. that's the reason the childhood vaccinations have been highlighted, we are just saving money of these vaccinations instead of thinking about the loss of a healthy life ${ }^{2}$. The vaccination compliance totally depends upon the knowledge and perception of parents about vaccines ${ }^{3}$. There is greatest need to emphasize on childhood vaccination in area of public health services ${ }^{4}$. Under developed and developed countries parents may not be completely aware about the vaccines despite the fact that many sources of information to know about the purpose of vaccination. There should be a good communication between parents and physician just to tell them the benefits of vaccines so that the vaccination rate could increase in a particular country. In US, the parents who hesitate about vaccines are directed to the Centers for Disease Control and Prevention. Some physicians recommend patient childhood vaccinations to the parents and influence parent's perception about vaccines. The parent should also not feel hesitated to ask any thing about the child's vaccination ${ }^{5}$. According to a national telephone survey conducted in 1999, the parent's compliance was marked low because they believe childhood diseases are less common; the lack of awareness and perception about vaccine risk were noted as the reasons of low compliance ${ }^{6}$. Researches from past have shown that parent's and health care providers at attitude and knowledge about vaccination greatly influence the vaccination coverage rate in a community ${ }^{7-8}$. In the past 15 years a technique has been emerged, to mark the difference between the vaccinated and unvaccinated individuals suffering from a same disease is known as vaccine probe. However traditional studies tell the usefulness efficacy and ability of a vaccine against the particular pathogenesis ${ }^{9}$. Measles, polio, mumps rubella are listed under vaccine preventable diseases. Thus the no. of vaccines used by the citizens of a country is reported to know about the level of protection, prevalence, awareness as well as compliance. For instance, Public Health Agency of Canada. Vaccine coverage in Canadian children: Results from the 2013 childhood National Immunization Coverage Survey $^{10}$. Two doses of the measles-mumps-rubella (MMR)are recommended to children before starting school: one between 12 and 15 months and other after or 
at 18 months of age by The National Advisory Committee on Immunization ( $\mathrm{NACl}$ ) however first dose of MMR or MMRV is recommended at 12 months and other at 18 months, 36 months or between 4 and 6 years of age by all provincial and territorial vaccination schedules ${ }^{11}$. Vaccination of children has really reduced the burden of infectious diseases ${ }^{12}$ but these Disease could not be proscribed without improving the health education of parents and without proper key family practice of the child vaccination $^{13}$.

\section{METHODOLOGY}

A cross sectional study was conducted among the parents of young children ( $\leq 5$ years) for the period of 7 months from June 2019 to December 2019 in a private tertiary care hospital of Karachi. A tertiary care teaching hospital was selected for collecting the data. For Collection of data, pediatric out patient's department and emergency department was targeted. After reviewing the abundant amount of relevant data a questionnaire was constructed to assess the parental knowledge attitude and perception (KAP) regarding the vaccinations among their child. Five Likert answer Scale Questionnaire was divided into 3 sections, section-A contained questions related to the knowledge of vaccinations, Section-B for the attitudes and beliefs of the parents' and Section-C for routine practice of the parents. Incomplete questionnaires i.e. $<50 \%$ of completed questions were excluded from the study.Data was entered in Ms excel, later transferred into SPSS version $\mathbf{2 0 . 0}$ for assessment and tabulations. The demographic characteristics were displayed by frequencies and percentages.A pilot study was conducted among 25 parents to check and optimize clarity of questionnaire. During pilot study the total time for completion the questionnaire was estimated 10-15 minutes

\section{RESULTS}

Total of 450 completely filled questionnaires were analyzed and demographic characteristics of respondents indicates female parent's respondents were found $78.7 \%$ ( $n=354)$ while $21.3 \%(n=96)$ were male respondents. Age group of the parents indicate $18-29$ years were $15.5 \%$ $(n=69), 44.7 \%(n=201)$ of parents were from group 30-39 years, while $39.8 \%(n=179)$ of parents were from 40 years and above. $46.2 \%(n=208)$ of parents had more than 3 children younger than the age of 5 years, $19.2 \%(n=86)$ of parents were found with 1 child less than the age of 5 years, while $34.7 \%(n=156)$ of parents found to have 2 children. Parents were asked about the source of information regarding vaccination for their children, most of parent's i.e. $73.6 \%(n=331)$ respondent that the only source of information regarding vaccination and immunization is their pediatrician or health consultants. 9.3\% $(n=41)$ of parents responded their family and relatives/ friends as source of information regarding vaccination while $17.1 \%(n=76)$ considered media as the source of information. Demographic characteristics are shown in table no. 1
Table 1: Demographic characteristics

\begin{tabular}{|c|c|c|}
\hline Variables & Respondents & Percent \\
\hline Male & 96 & $21.3 \%$ \\
\hline Female & 354 & $78.7 \%$ \\
\hline Total & 450 & $100 \%$ \\
\hline \multicolumn{3}{|c|}{ Age groups } \\
\hline $18-29$ year & 70 & $15.5 \%$ \\
\hline $30-39$ years & 201 & $44.7 \%$ \\
\hline$>40$ years & 179 & $39.8 \%$ \\
\hline \multicolumn{3}{|c|}{ No of children } \\
\hline 1 & 86 & $19.1 \%$ \\
\hline 2 & 156 & $34.7 \%$ \\
\hline$\geq 3$ & 208 & $46.2 \%$ \\
\hline \multicolumn{3}{|c|}{ Source of information } \\
\hline Family/friend & 42 & $9.3 \%$ \\
\hline Doctors & 331 & 73.6 \\
\hline Media & 77 & 17.1 \\
\hline Education & \multicolumn{2}{|c|}{ Status } \\
\hline Educated & 376 & $83.6 \%$ \\
\hline Uneducated & 74 & 16.4 \\
\hline
\end{tabular}

Later on, parents were asked regarding the history of immunization and previous records of vaccinations, $85.4 \%$ $(n=384)$ of parents said that their child vaccination record is safely kept while $14.5 \%(n=65)$ of parents were without any previous record of vaccination. $6.79 \% \quad(n=30)$ of parents marked their children has already suffered from the preventable diseases while majority of parents had no idea about the past sufferings of their child from preventable diseases. 66\% $(n=297)$ of parents clearly denied from their child never suffered such diseases. Table: 2 .

On response to question of Source of vaccinating their child $63.8 \%(n=287)$ of parents responded self-paid $33.1 \%$ $(n=149)$ of parents stated they can achieve the free community services regarding vaccination. While $3.1 \%$ $(n=14)$ of parents stated they are funded by companies and other means. Shown in table 2.

Upon asking about the possible side effects that a vaccines can produce; $8.9 \%$ of parents strongly agreed stated that a vaccination can produce side effects and can harm their children, while $65.8 \%$ of parent's remained uncertain about the statement. To assess the knowledge of parents regarding the origin of vaccines, parents were provided with the statement i.e. vaccines is an antibody originated from infected source, $14.2 \%$ of parents accepted agreed and $69.6 \%$ of parents remained uncertain.

Upon asking about the possible side effects that a vaccines can produce; $8.9 \%$ of parents strongly agreed stated that a vaccination can produce side effects and can harm their 
children, while $65.8 \%$ of parent's remained uncertain about the statement. To assess the knowledge of parents regarding the origin of vaccines, parents were provided with the statement i.e. vaccines is an antibody originated from infected source, $14.2 \%$ of parents accepted agreed and $69.6 \%$ of parents remained uncertain.

Table 2: History of immunization and previous records of vaccinations

\begin{tabular}{|c|c|c|c|c|}
\hline \multirow{5}{*}{$\begin{array}{l}\text { Have your child } \\
\text { received vaccination } \\
\text { for; }\end{array}$} & Names of vaccines & Yes & No & Don't know \\
\hline & Influenza & $375(83.3 \%)$ & $27(6 \%)$ & $48(10.7 \%)$ \\
\hline & Pertussis & $369(82 \%)$ & $19(4.2 \%)$ & $62(13.8 \%)$ \\
\hline & Pneumonia & $401(89.1 \%)$ & $8(1.8 \%)$ & $41(9.1 \%)$ \\
\hline & Hepatitis & $344(76.4 \%)$ & $101(22.4 \%)$ & $5(1.1 \%)$ \\
\hline \multirow{3}{*}{$\begin{array}{l}\text { Already suffered } \\
\text { preventable disease }\end{array}$} & \multicolumn{2}{|l|}{ Yes } & 30 & $6.7 \%$ \\
\hline & \multicolumn{2}{|l|}{ No } & 297 & $66 \%$ \\
\hline & \multicolumn{2}{|c|}{ Don't know } & 123 & $27.3 \%$ \\
\hline \multirow{2}{*}{$\begin{array}{l}\text { Whether patient has } \\
\text { record of previous } \\
\text { vaccinations }\end{array}$} & \multicolumn{2}{|l|}{ Yes } & 384 & $85.3 \%$ \\
\hline & \multicolumn{2}{|l|}{ No } & 66 & $14.7 \%$ \\
\hline \multirow{3}{*}{$\begin{array}{ll}\text { Source } & \text { of } \\
\text { vaccinating child }\end{array}$} & \multicolumn{2}{|c|}{ Self } & 287 & $63.8 \%$ \\
\hline & \multicolumn{2}{|c|}{ Free community service } & 149 & $33.1 \%$ \\
\hline & \multicolumn{2}{|c|}{ Others } & 14 & $3.1 \%$ \\
\hline
\end{tabular}

Table 3: Assessment of knowledge and attitude towards vaccinations.

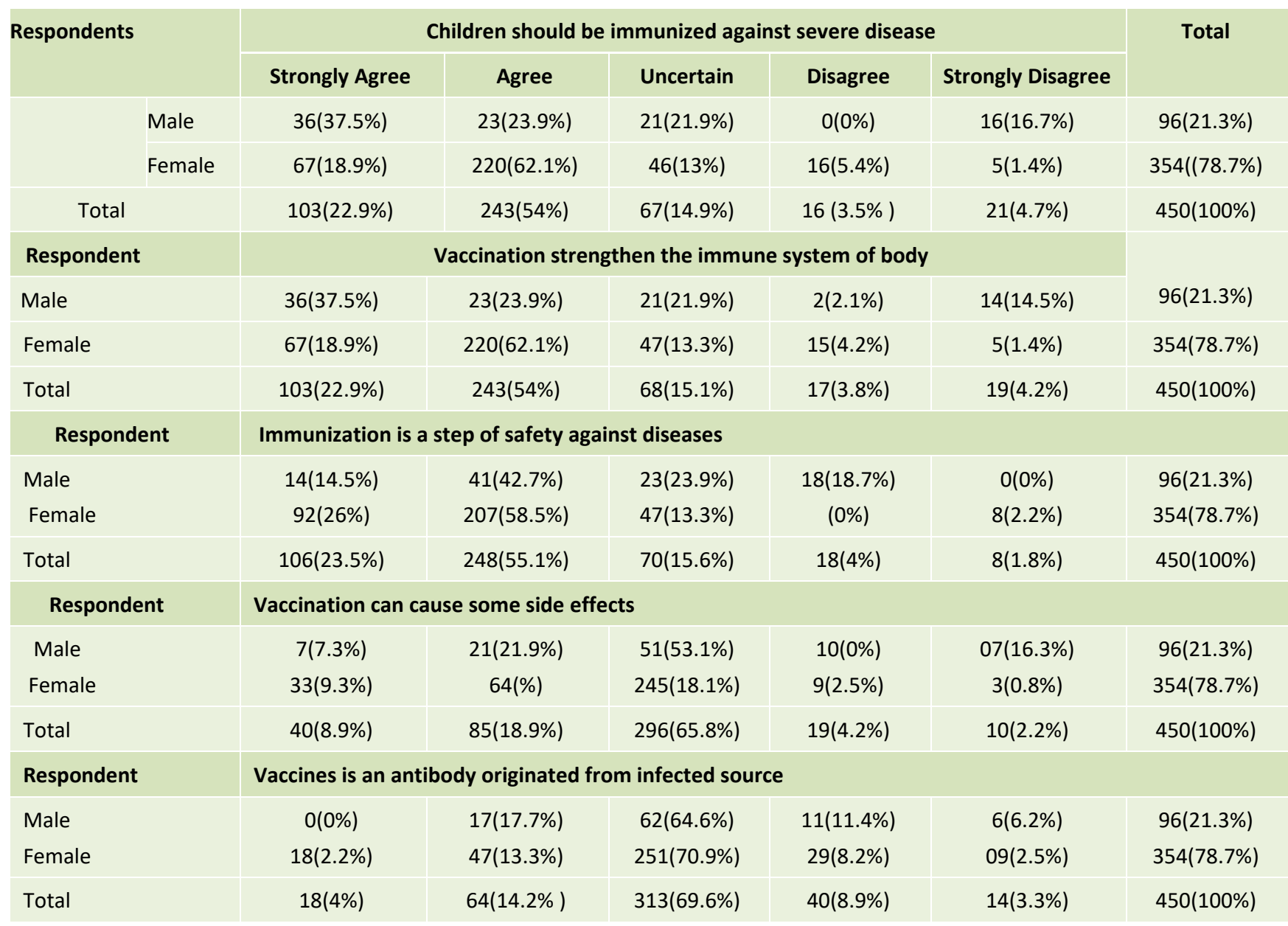


Table 4: Assessment of parent's attitude and practice regarding vaccination

\begin{tabular}{|c|c|c|}
\hline $\begin{array}{l}\text { Parents } \\
\text { response }\end{array}$ & \multicolumn{2}{|c|}{$\begin{array}{l}\text { How often did you ask your doctors } \\
\text { about necessity of vaccination in } \\
\text { child health }\end{array}$} \\
\hline \multirow{2}{*}{$\begin{array}{l}\text { Always Most of } \\
\text { the time }\end{array}$} & 76 & $16.9 \%$ \\
\hline & 68 & $15.1 \%$ \\
\hline Often & 296 & $65.8 \%$ \\
\hline Some times & 0 & $0 \%$ \\
\hline Never & 10 & $2.2 \%$ \\
\hline $\begin{array}{l}\text { Response of } \\
\text { parents }\end{array}$ & \multicolumn{2}{|c|}{$\begin{array}{l}\text { How often did you found the side } \\
\text { effects after vaccination }\end{array}$} \\
\hline Always & 0 & $0 \%$ \\
\hline $\begin{array}{l}\text { Most of the } \\
\text { time }\end{array}$ & 26 & $11.3 \%$ \\
\hline Often & 76 & $32.9 \%$ \\
\hline Some time & 74 & $32.0 \%$ \\
\hline Never & 55 & $23.8 \%$ \\
\hline $\begin{array}{l}\text { Response of } \\
\text { parents }\end{array}$ & \multicolumn{2}{|c|}{$\begin{array}{l}\text { How often did you completely } \\
\text { followed the doctor's instruction }\end{array}$} \\
\hline Always & 107 & $23.8 \%$ \\
\hline $\begin{array}{l}\text { Most of the } \\
\text { time }\end{array}$ & 70 & $15.5 \%$ \\
\hline Some time & 70 & $15.6 \%$ \\
\hline Never & 5 & $1.1 \%$ \\
\hline often & 198 & $44 \%$ \\
\hline $\begin{array}{l}\text { Response of } \\
\text { parents }\end{array}$ & \multicolumn{2}{|c|}{$\begin{array}{l}\text { How often did you ask for } \\
\text { information about the vaccination } \\
\text { from your doctor }\end{array}$} \\
\hline Always & 122 & $27.1 \%$ \\
\hline $\begin{array}{l}\text { Most of the } \\
\text { time }\end{array}$ & 30 & $6.7 \%$ \\
\hline Often & 94 & $20.9 \%$ \\
\hline Sometimes & 178 & $39.5 \%$ \\
\hline Never & 26 & $5.8 \%$ \\
\hline $\begin{array}{l}\text { Response of } \\
\text { parents }\end{array}$ & \multicolumn{2}{|c|}{$\begin{array}{l}\text { Have you omitted the important } \\
\text { vaccination for your child advised } \\
\text { by doctor }\end{array}$} \\
\hline Always & 30 & $6.7 \%$ \\
\hline $\begin{array}{l}\text { Most of the } \\
\text { time }\end{array}$ & 52 & $11.7 \%$ \\
\hline Often & 75 & $16.7 \%$ \\
\hline Sometimes & 198 & $44 \%$ \\
\hline Never & 94 & $20.9 \%$ \\
\hline $\begin{array}{l}\text { Response of } \\
\text { parents }\end{array}$ & \multicolumn{2}{|c|}{$\begin{array}{l}\text { I feel worried \& keep asking about } \\
\text { vaccination }\end{array}$} \\
\hline Always & 106 & $23.5 \%$ \\
\hline $\begin{array}{l}\text { Most of the } \\
\text { time }\end{array}$ & 91 & $20.2 \%$ \\
\hline Often & 52 & $11.6 \%$ \\
\hline Sometimes & 103 & $22.9 \%$ \\
\hline Never & 98 & $21.8 \%$ \\
\hline
\end{tabular}

Assessment of parent's attitude and practice regarding vaccination (Table 4)

Parents were given with questions of Section c to assess their practice against vaccination and immunization approach, parents were asked how often they ask regarding safety \& importance of vaccination for their child, on response basis it was found $16.9 \%$ of parents always questions regarding the importance of vaccination while $23.8 \%$ parents always followed the instructions of their pediatrician. 44\% parents sometime omitted the important vaccination for your child advised by doctor. $23.5 \%$ parents feel worried \& keep asking about vaccination. Some parents responded that they always feel worried regarding the immunity of their child and keep asking their child's pediatrician regarding the vaccination and vaccination schedule.

\section{DISCUSSION}

Practice of vaccination remains always a big challenge for Pakistan. The vaccination in childhood has shown prevention to disease \& death among children and vaccination is essential to keep children healthy ${ }^{13}$. Thus KAP survey of parents towards childhood vaccination is very important to upgrade the health as well as diseases prevention. According to the findings of this study the trends has been showed the knowledge, attitudes and practices of parents regarding childhood vaccination.

This study has identified and assesses the parent's knowledge attitude and perception (KAP) regarding the vaccinations among their child. Questions were divided into different three sections according to KAP studies, section A contained questions related to the knowledge of vaccinations, section $B$ for the attitudes and beliefs of the parents' and section C for routine practice of the parents. The good KAP results show a significant association between female gender as well as awareness about vaccination and their role because mothers are prim care giver and spend most time with children as compare to fathers.

This study showed that total 450 responses were correct fill the questioner in which 21.3 recorded with male gender and remaining were females preponderance (78.7\%). As for the gender, female preponderance is higher because mothers are the main care giver and more time with their kids than fathers ${ }^{14}$. Most of the parents (44.7\%) were reported in age group of $30-39$ years.83.6\% parents were educated and their source of information was doctors (73.6\%). Other studies were also show that parent's education is more important for good health of their child and to appreciate the value of vaccination for their children. In section $A$, three questions were asked to parents about knowledge of vaccinations. Results shows that mostly of patients (85.4\%) kept records their child vaccination and parent's knowledge and $66 \%$ of parents clearly deprived of that their child never suffered such disease. In section B, results shows that perception regarding vaccinating their children was found to be $22.9 \%$ 
of parents were strongly agreed and 54\% agreed. A prospective intervention study from Karachi had also proved that education of vaccination for mothers of child will improve the health of their kids. These finding is not similar to other studies ${ }^{15-16}$ which shows that parents had low knowledge regarding vaccination adverse effects. About $55.1 \%$ patients were agreed about Immunization is a step of safety against diseases. This finding is similar to results in previous studies, in which more than $83 \%$ of parent's privileged child vaccination ${ }^{17-19}$.

However, literature reviews show that only has a good knowledge about vaccination is not sufficient to have good health care. A favorable attitude \& perseverance is required for correct practices of health care and a positive attitude was showed among parents who were aware about vaccines and their benefits. In section $C$, six questions were asked to parents which show parents response for routine practice Outcomes of study showed that $44 \%$ parents sometime omit the important vaccination for your child advised by doctor and $23.5 \%$ parents worried \& keep asking about vaccination ${ }^{20-21}$.

\section{CONCLUSION}

Our study concluded that most of the participants parents have some awareness regarding vaccination and wanted to know about the vaccine benefits. Further health education is given to parents to improve detailed knowledge about vaccination i.e. type of vaccination and their timing. Heath education is also required: 1 . To improve attitude about vaccination i.e. their importance in health care of child 2 . To improve their perception regarding safety/adverse effects of vaccine. 3 . To improve practice of vaccination.

\section{REFERENCES}

1. Aysha, Z, Vaccine effectiveness and risk factors associated with measles among children presenting to the hospitals of Karachi, Pakistan, Journal of the College of Physicians and Surgeons Pakistan, 24(12), 2014, PP 822-888.

2. Muppidathi, S., Boj, J. and Deivanayagam, S, Knowledge on rotavirus and pneumococcal vaccines among mothers of under five children. International Journal of Contemporary Pediatrics, 4(5), 2017, PP 1739-1742.

3. Zhang, M., Zhang, J., Hao, Y., Fan, Z., Li, L., Li, Y., Wu, $D$, Vaccination knowledge, attitude and practice among Chinese travelers who visit travel clinics in Preparation for international travel. Journal of travel medicine, 23(6), 2016, PP 50-51.

4. Similjana J, knowledge and attitude towards vaccinations: a servey of Serbian students, Journal of infections and public health, 10(8), 2017, PP649-656

5. Henrikson, N. B., Opel, D. J., Grothaus, L., Nelson, J., Scrol, A., Dunn, J., ... \& Grossman, D, Physician communication training and parental vaccine hesitancy: a randomized trial. Pediatrics, 136(1), 2015, PP 70-79.

6. Fredrickson, D. D., Davis, T. C., Arnould, C. L., Kennen, E. M., Humiston, S. G., Cross, J. T., \& Bocchini, J. A, Childhood immunization refusal: provider and parent perceptions. Family Medicine-Kansas City-, 36, 2004, PP 431-439.

7. Gust DA, Strine TW, Maurice E, Smith $P$, Yousuf $H$, Wilkison $\mathrm{M}$, et al., underimmunization among children: effects of vaccine safety concern onn immunization status. Pediatrics, 114, 2004, PP 16-22

8. Weigel M, Weithmann K, Rautmann C, Schmidth J, Bruns $R$, impact of physcian's attitude to vaccination on local vaccination coverage of pertussis and measles in Germany, Eur J Public Health 24(6) 2014, PP 100916

9. Feikin, D.R., Scott, J.A.G. and Gessner, B.D, Use of vaccines as probes to define disease burden. The Lancet, 383(9930), 2014, PP 1762-1770.

10. Masadeh, M. M., Alzoubi, K. H., Al-Azzam, S. I., AlAgedi, H. S., Abu Rashid, B. E., \& Mukattash, T. L. Public awareness regarding children vaccination in Jordan. Human vaccines \& immunotherapeutics, 10(6), 2014, PP 1762-1766.

11. Périnet, S., Kiely, M., De Serres, G. and Gilbert, N.L, Delayed measles vaccination of toddlers in Canada: Associated socio-demographic factors and parental knowledge, attitudes and beliefs. Human vaccines \&immunotherapeutics, 14(4), 2018, PP 868-874.

12. NafehaSameen Siddiqui, Arvind K. Gaikwad, Bina M. Kuril, Rajendra T. Ankushe, Mohan K. Doibale, Sandeep B. Pund, Purushottam Kumar: Is mothers' knowledge and practice regarding childhood immunization compliant with immunization completeness? International Journal of Community Medicine and Public Health, 4(3), 2017, PP 775-780.

13. Zahidie, A., Wasim, S., \& Fatmi, Z, Vaccine effectiveness and risk factors associated with measles among children presenting to the hospitals of Karachi, Pakistan. Journal of the College of Physicians and Surgeons Pakistan, 24(12), 2014, PP 882.

14. Shaikh, S, Impact of an IEC (Information, Education and Communication) intervention on key family practices of mothers related to child health in Jamshoro, Sindh. Pak J Med Sci, 30(3), 2014 PP 611-8.

15. Northrop-Clewes, C.A., et al., Impact of health service provision on mothers and infants in a rural village in North West Frontier Province, Pakistan. Public Health Nutr, 1(1), 1998, PP 51-9

16. Zulfiqar Ali, Sathirakorn Pongpanich, Ramesh Kumar, Abdul Ghaffar, Sheh Murred and Rana Muhammad Safdar .Routine Immunization Status among Children under 5 Years of Age living in Rural District of Pakistan. 
International Journal of Health Research and Innovation, 3(2), 2015, PP 13-20

17. Agboatwalla, M. and D.S. Akram, Impact of health education on mothers' knowledge of preventive health practices. Trop Doct, 27(4), 1997, PP. 199-202.

18. Hassan A, A. S., Yahya M, A. S., Tariq A, A. A., \& Hussamaldin Tariq A, A, Assessment of knowledge and Attitude and Practice of Parents towards Epilepsy among Children in Abha City. The Egyptian Journal of Hospital Medicine, 72(3), 2018, PP 4060-4063.

19. Gentile A. Delayed vaccine schedule and missed opportunities for vaccination in children up to 24 months: a multicenter study. Arch Argent Pediatr, 109(3), 2011, PP 219-25
20. Al-Lela, O. Q. B., Bahari, M. B., Al-Qazaz, H. K., Salih, M. R., Jamshed, S. Q., \& Elkalmi, R. M, Are parents' knowledge and practice regarding immunization related to pediatrics' immunization compliance? a mixed method study. BMC pediatrics, 14(1), 2014, PP 1-7.

21. Saleh, A., Alrashidi, A. A., Bukhari, M. A., Habib, R. F., Alsubhi, R. A., Saadawi, D. W., \& Hatim, R. F. L. A, Assessment of knowledge, attitude and practice of parents towards immunization of children in Saudi Arabia, 2018. The Egyptian Journal of Hospital Medicine, 71(2), 2018, PP 2585-2589.

Source of Support: None declared.

Conflict of Interest: None declared.

For any question relates to this article, please reach us at: editor@globalresearchonline.net New manuscripts for publication can be submitted at: submit@globalresearchonline.net and submit_ijpsrr@rediffmail.com 